\title{
Occupational exposure to blood and body fluids and associated factors among health care workers at the University of Gondar Hospital, Northwest Ethiopia
}

\author{
Jemal Yasin ${ }^{1}$, Roman Fisseha ${ }^{2}$, Feleke Mekonnen ${ }^{2}$ and Ketsela Yirdaw ${ }^{3^{*}}$
}

\begin{abstract}
Background: Occupational exposure to blood and body fluids (BBFs) is a serious concern for health care workers (HCWs) and presents a major risk factor for transmission of infectious diseases such as hepatitis B virus (HBV), hepatitis $C$ virus, and human immune deficiency virus. The main objective of this study was to assess the magnitudes of occupational exposure of blood and body fluids and associated factors among health workers at the University of Gondar Hospital.

Methods: An institution-based cross-sectional study was conducted from 1 February to 31 May 2017 at the University of Gondar Hospital. A total of 282 health care workers were selected by simple random sampling technique. Descriptive data was presented as absolute number with percentage, and multivariate analysis was used to assess the statistical association between associated factors and occupational exposure to BBFs. A $P$ value of $<0.05$ was considered as statistical significant.

Result: A total of $282 \mathrm{HCWs}$ participated with the mean ( \pm SD) age of $30.51 \pm 5.86$ year. Of the total, 58.5\% (165) and $42.2 \%$ (119) of the study participants had been exposed to BBFs splash and needlestick injury (NSI) in their lifetime, respectively. However, $39.0 \%$ (110) and 20.6\% (58) of the HCWs were exposed to splash and NSI in the past 1 year, respectively. Not wearing eye goggle, lack of training on infection prevention, taking of HBV vaccination, and recapping of used needle were risk factors associated with BBFs splash exposure, whereas taking HBV vaccination and recapping of used needle were associated risk factors with NSI exposure.

Conclusion: This study showed a high percentage of occupational exposure to blood and body fluids among health care workers. Not wearing eye goggle, HBV vaccine status, and recapping needles were found to be independent predictors of occupational exposure to BBFs among HCWs. Therefore, relevant stakeholders need to formulate strategies to create a favorable working environment and increase their adherence to universal precautions.
\end{abstract}

Keywords: Occupational exposure, Health care workers, Blood and body fluids

\footnotetext{
* Correspondence: ketselayirdaw@yahoo.com

${ }^{3}$ Department of Clinical Chemistry, School of Biomedical and Laboratory

Sciences, College of Medicine and Health Sciences, University of Gondar, P.O.

Box 196, Gondar, Ethiopia

Full list of author information is available at the end of the article
}

(c) The Author(s). 2019 Open Access This article is distributed under the terms of the Creative Commons Attribution 4.0 International License (http://creativecommons.org/licenses/by/4.0/), which permits unrestricted use, distribution, and reproduction in any medium, provided you give appropriate credit to the original author(s) and the source, provide a link to the Creative Commons license, and indicate if changes were made. The Creative Commons Public Domain Dedication waiver (http://creativecommons.org/publicdomain/zero/1.0/) applies to the data made available in this article, unless otherwise stated. 


\section{Background}

Occupational exposure to blood and body fluid is the accidental contact with blood and body fluids during a medical intervention by HCWs. These unintended exposures to BBFs carry the risk of infection by various blood-borne viruses. It constitutes a major risk for the transmission of infections such as human immune deficiency virus (HIV), HBV, and hepatitis $\mathrm{C}$ virus (HCV). This is one of the serious public health problems that HCWs encounter [1].

HCWs are at high risk of being infected with various diseases transmitted by blood and body fluids due to frequent exposure to biological materials and patient's body fluids. Needle injuries and injuries due to cutting, biting, or splashing incidents are some of the ways HCWs encounter during their daily activities [2]. The frequency of needlestick injuries and high prevalence of blood-borne diseases in the general population have a great impact on the exposure of different infection agent risk among HCWs [3]. Infectious complications associated with needle stick injury can result in a variety of serious and stressing consequences ranging from mild to extreme anxiety among HCWs [4]. It is very important that HCWs undergo follow-up assessments after being exposed to BBFs for the detection and early treatment of acute infection, such as HCV [5].

Blood of patient with HBV contains the highest HBV level than other body fluids and is the most important source of transmission in the health care center. Cerebrospinal fluid, synovial fluid, pleural fluid, peritoneal fluid, pericardial fluid, and amniotic fluid potential are considered also potentially infectious [6]. Currently, $\mathrm{HBV}$ is the only one that has a vaccine from three serious viral infections (HBCV, HCV, and HIV) [7]. HCWs who have received hepatitis $B$ vaccine are at almost no risk for infection [8].

The World Health Organization estimated that 3 million are exposed to blood-borne viruses each year and $90 \%$ of the exposures occur in the developing countries [9]. In developing countries, HCWs are at serious risk of infection from blood-borne pathogens particularly $\mathrm{HBV}, \mathrm{HCV}$, and HIV because of the high prevalence of such pathogens in general population, particularly sub-Saharan Africa [10].

Occupational hazards faced by HCWs in Ethiopia have received increasing attention but existing surveillance system and HCWs responsiveness for safety precautions are insufficient to describe the scope and extent of occupational exposure to the infectious agent that HCWs experience, the outcomes of these exposures and injuries, and the impact of preventive measures. So the aim of our study was to show the magnitude of occupational exposure to BBFs and to point out the main associated factors. Hence, these findings would provide pertinent information to reduce the exposure of HCWs to blood and body fluids. Moreover, our study provides current updated and baseline information, as well as recommendations for further corrective actions by researchers, governmental, and non-government responsible bodies and other stack holders.

\section{Methods}

The study was conducted in Gondar town, Northwest Ethiopia, which is located $737 \mathrm{~km}$ from Addis Ababa the capital city of Ethiopia. The University of Gondar Hospital is a referral hospital which gives medical service to more than 5 million inhabitants in and around Gondar. Currently, it has 446 functional beds for admitting patients and it has senior level to medium level professionals working at pediatrics, surgery, gynecology, psychiatry, HIV care, laboratory, and other service delivery centers.

A cross-sectional study design was conducted to assess occupational exposure on blood and body fluids on HCWs at the University of Gondar Teaching Referral Hospital. The study was conducted from 1 February 1 to 31 May 2017. Single population proportion formula was used by using $62.9 \%$ of the prevalence of occupational exposure to BBFs in the previous study [4]. By considering a 5\% margin of error and 95\% confidence interval, a total of 282 health care workers were obtained. A stratified sampling technique was used to distribute total sample size based on their profession. The study participants were selected by a simple random sampling technique.

A self-administered structured questionnaire was used to collect information about socio-demographic characteristics, HBV vaccination standard precautions use, working environment, and occupational exposure of HCW to BBFs based on the previous studies $[11,12]$. HCWs were considered as exposed to NSI if the HCW had a history of one or more of a needlestick or sharps injury whereas HCWs are considered exposed to BBFs splash if the HCW had a history of a splash of any body fluids onto their mucous membranes or skin. In this study, lifetime exposure indicates exposure of the HCWs to BBFs in their career whereas the past one was to indicate recent exposure to BBFs. All the study participants were informed about the purpose of the study and informed consent was obtained from the participants.

Data were entered, cleaned, and analyzed using SPSS for window, version 20 (SPSS Inc., Chicago, IL, USA) statistical package software. Descriptive statistics like frequencies and proportions were used to summarize the data. Crude odds ratio (COR) and adjusted odds ratio (AOR) with their 95\% confidence interval were expressed to describe the association of risk factors with BBFs exposure in univariate and multivariate analysis respectively. Univariate analysis was employed to examine the relationship between the dependent variables and independent variables. Those variables with observed association of $P<0.25$ on 
univariate analysis were further treated by multivariate analysis in order to adjust for possible confounders. A $P$ value $<0.05$ was considered significant.

\section{Results}

Socio-demographic characteristics of health care workers A total of 282 health care workers participated in this study; a response rate of $96.9 \%$. Among the respondents, $53.9 \%$ (152) were males. The age range of study subjects was from 23 to 53 years with the mean $( \pm S D)$ age of $30.51 \pm 5.86$ years. Regarding the educational status, $87.2 \%$ (246) of HCWs had a bachelor degree and above. From the total HCWs, 45\% (127) had experience between 2 and 5 years of service (Table 1).

\section{Prevalence of occupational exposure to BBFs}

Of the total, 58.5\% (165) study participants had been exposed to BBFs splash in their lifetime. However, 39.0\% (110) of HCWs were exposed to BBFs splash in the past year. Histories of needlestick injury over their lifetime and in the past year were $42.2 \%$ and $20.6 \%$, respectively (Table 2).

\section{Distribution of common factors with occupational exposures of blood and body fluids}

From the study participants, 39.36\% (111) have been trained in occupational infection prevention. Seventy-seven percent (65) of the study participants responded that there were not enough personal protective equipment (PPE) available over the past year which refers basic wear to create a barrier between personnel and germs such as wearing gloves, masks, eye protection, and clothing. The presence of safety signs in the working area was answered by $25.9 \%$ (73) of the study participants. The majority (94\%) of the study participants had used gloves during the last health care procedure. Seventy-two percent (203) of the study participants had enough hand washing facilities in their working area. Nearly 90\% (252) of HCWs washed their hands before and after any health care procedure as well as handling and processing of BBFs. A total of 55.3\% (156) study participants were vaccinated for HBV. 70.6\% (199) of

Table 1 socio-demographic characteristics of health care workers

\begin{tabular}{|c|c|c|c|}
\hline Variables & Result & Frequency (\#) & Percentage (\%) \\
\hline \multirow[t]{2}{*}{ Sex } & Male & 152 & 53.9 \\
\hline & Female & 130 & 46.1 \\
\hline \multirow[t]{3}{*}{ Age } & $18-30$ & 169 & 59.9 \\
\hline & $31-40$ & 97 & 34.4 \\
\hline & $>40$ & 16 & 5.7 \\
\hline \multirow[t]{2}{*}{ Educational status } & Certificate and diploma & 36 & 12.8 \\
\hline & Degree and above & 246 & 87.2 \\
\hline \multirow[t]{5}{*}{ Profession } & Nurse & 180 & 63.8 \\
\hline & Diagnostic laboratory & 27 & 9.6 \\
\hline & Medical doctor & 13 & 4.6 \\
\hline & Midwife & 27 & 9.6 \\
\hline & Others & 35 & 12.4 \\
\hline \multirow[t]{9}{*}{ Department } & Outpatient & 67 & 23.8 \\
\hline & Injection and dressing & 16 & 5.7 \\
\hline & Surgical ward & 18 & 6.4 \\
\hline & Operation room & 27 & 9.6 \\
\hline & Pediatric ward & 17 & 6.0 \\
\hline & Gynecology ward & 46 & 16.3 \\
\hline & Medical ward & 30 & 10.6 \\
\hline & Diagnostic laboratory & 25 & 8.9 \\
\hline & Others & 36 & 12.8 \\
\hline \multirow[t]{4}{*}{ Work experience } & $<2$ years & 57 & 20.2 \\
\hline & $2-5$ Years & 127 & 45.0 \\
\hline & $6-9$ years & 72 & 25.5 \\
\hline & $\geq 10$ years & 26 & 9.2 \\
\hline
\end{tabular}


Table 2 Frequency of occupational BBFs splash and NSI exposure among health care workers

\begin{tabular}{|c|c|c|c|}
\hline Variables & Result & Frequency (\#) & Percentage (\%) \\
\hline \multirow[t]{2}{*}{ Lifetime occupational exposure to splash } & Yes & 165 & 58.5 \\
\hline & No & 117 & 41.5 \\
\hline \multirow[t]{2}{*}{ The past 1-year occupational exposure to splash } & Yes & 110 & 39.0 \\
\hline & No & 172 & 61.0 \\
\hline \multirow[t]{2}{*}{ Lifetime occupational exposure to NSI } & Yes & 119 & 42.2 \\
\hline & No & 163 & 57.8 \\
\hline \multirow[t]{2}{*}{ The past 1-year occupational exposure to NSI } & Yes & 58 & 20.6 \\
\hline & No & 224 & 79.4 \\
\hline
\end{tabular}

BBFs blood and body fluids, NSI needlestick injury

HCWs did not have information on the availability of an infection prevention committee in the health institution. Moreover, 173 study participants responded that the workplace was not safe for the prevention of occupational exposure to BBFs (Table 3).
Factors associated with occupational exposure

The univariate analysis showed significant association between BBFs splash exposure and the following risk factor's age, department, training on infection prevention, wearing of eye goggle, and availability of enough

Table 3 Distribution of common factors to occupational exposures of blood and body fluids among health care workers

\begin{tabular}{|c|c|c|c|}
\hline Variables & Results & Frequency (\#) & Percentage (\%) \\
\hline \multirow[t]{2}{*}{ Training on occupational infection prevention } & Yes & 111 & 39.36 \\
\hline & No & 171 & 60.64 \\
\hline \multirow[t]{2}{*}{ Practicing universal precaution and safety } & Yes & 124 & 44.0 \\
\hline & No & 158 & 56.0 \\
\hline \multirow[t]{2}{*}{ Availability of adequate PPEs } & Yes & 65 & 23.0 \\
\hline & No & 217 & 77.0 \\
\hline \multirow[t]{2}{*}{ Availability of safety signs in the workplace } & Yes & 73 & 25.9 \\
\hline & No & 209 & 74.1 \\
\hline \multirow[t]{2}{*}{ Wearing of gloves during handling and processing of BBFs } & Yes & 265 & 94.0 \\
\hline & No & 17 & 6.0 \\
\hline \multirow[t]{2}{*}{ Wearing of eye goggle during handling and processing of BBFs } & Yes & 43 & 15.2 \\
\hline & No & 239 & 84.8 \\
\hline \multirow[t]{2}{*}{ Safety of the workplace in the prevention of exposure to BBFs } & Yes & 109 & 38.7 \\
\hline & No & 173 & 61.3 \\
\hline \multirow[t]{2}{*}{ Availability of adequate hand washing facilities in the workplace } & Yes & 203 & 72.0 \\
\hline & No & 79 & 28.0 \\
\hline \multirow[t]{2}{*}{ Washing of hands before and after any procedure or process } & Yes & 252 & 89.4 \\
\hline & No & 30 & 10.6 \\
\hline \multirow[t]{2}{*}{ Availability of an infection prevention team } & Yes & 83 & 29.4 \\
\hline & No & 199 & 70.6 \\
\hline \multirow[t]{2}{*}{ HBV vaccinated } & Yes & 156 & 55.3 \\
\hline & No & 126 & 44.7 \\
\hline \multirow[t]{2}{*}{ Recapping of the used needle } & Yes & 126 & 44.7 \\
\hline & No & 156 & 55.3 \\
\hline \multirow[t]{2}{*}{ Applying of universal safety precaution standards } & Yes & 83 & 29.4 \\
\hline & No & 199 & 70.6 \\
\hline
\end{tabular}


washing facilities, the presence of safety sign, existence of infection prevention committee, having HBV vaccination, and recapping of used needles a value of $P<0.25$ (Table 4). However, age, department, training on infection prevention, wearing of eye goggle, the presence of safety sign and committee, having of HBV vaccination, and recapping of the used needle were significantly associated with NSI exposure (Table 5).

In the multivariate analysis, training on infection prevention ( $\mathrm{AOR}=2.17,95 \% \mathrm{CI} 1.25,3.7$ ), lack of wearing eye goggle $(\mathrm{AOR}=2.29,95 \% \mathrm{CI} 1.14,4.6)$, having $\mathrm{HBV}$ vaccination $(\mathrm{AOR}=1.82,95 \% \mathrm{CI} 1.08,3.03)$, and recapping of used needle (AOR $=2.22,95 \%$ CI $1.32,3.74)$ were found to be risk factors associated with occupational exposure to splash (Table 4), whereas only having HBV vaccination ( $\mathrm{AOR}=2.04,95 \% \mathrm{CI} 1.22,3.33)$ and recapping of used needle (AOR $=2.45,95 \%$ CI 1.49, 4.03) were found to be risk factors associated with NSI exposure (Table 5).

\section{Discussion}

The exposure of HCWs to BBFs during intervention has exposed them to different blood-borne diseases which in turn have had an impact on their health and health care services in many countries, particularly developing countries with limited human resources and poor infrastructure [13]. HCWs at the University of Gondar Hospital have to deal with a high load of patients; this fact combined with the urgency of some interventions contributes to this high prevalence of BBFs among studied groups.

In this study, $58.5 \%$ of $\mathrm{HCW}$ s were exposed to BBFs splash in their lifetime, which was lower than findings from Serbia (66\%), Iran (74\%), India (73\%), and Bahir Dar (74\%) [12, 14-16]. However, this study indicates higher percentage of HCWs exposed to blood and body fluids compared with the studies conducted in Kenya and Eastern Ethiopia [11, 17]. The reasons for this variation could be due to lack of regular training about safety precaution sand infection prevention, inadequate supervision by health administrators, and infrastructure development.

In the present study, $39.0 \%$ (110) of HCWs were exposed to BBFs splash in the past 1 year which was lower than the study conducted in Bahir Dar town (65.9\%) and previous study in Gondar University Hospital (62.9\%) [4, 12]. On the contrary, our findings revealed a higher percentage of HCWs exposed to BBFs when compared to studies done in Kenya (25\%), Brazil (7\%), and Bale Zone (19.1\%) [17-19]. This difference could possibly be due to the absence of continuous training on prevention of occupational infection, difference in infrastructure development, and low functionality of existing infection prevention committee as well as the experience of HCWs to adhere to standard occupational safety precautions.

National Institute of Occupational Safety and Health in the USA identifies the following as predisposing factors to needlestick injuries: over-use of injections, unnecessary sharps, lack of PPE supplies, failure to use sharps container immediately after use, poorly trained staff, needle recapping, no engineering control, such as safe needle devices, passing instruments from hand to hand in the operating room, and lack of hazard awareness [20]. This was in agreement with our findings in which $67.4 \%$ of staffs are untrained, facilities lack safety devices, and needle recapping is still practiced.

Our finding showed that $42.2 \%$ (119) of study participants were injured by needlestick injury in their lifetime, which was lower than studies done in India (63\%) and Bahir Dar town $(50 \%)$ [12, 16]. However, our finding on the needlestick injury in the past 1 year, $20.6 \%$ (58) was almost comparable with finding from Bale Zone (19\%) [19]. On the other hand, our study was higher than studies from Iran $(8 \%)$ and Dire Dawa $[11,15]$. This difference might be due to variations in the health care setting, the availability of PPE in health care facilities, and training about infection prevention.

In this study, 44\% (124) of the HCWs practiced universal precaution and safety, which was slightly higher than the study conducted in public health facilities in Mekelle special zone [21]. On the other hand, 39.36\% (111) of study participants had training on infection prevention, and the finding is similar to the study conducted in India [22]. However, the level of training on infection prevention was lower compared to studies in Eastern Ethiopia and Debrebirhan Town [11, 23]. This could be due to the lack of commitment, limited budget available to support training, and capacity building.

Hepatitis B vaccination coverage among HCWs in our study was $55.3 \%$ (156), which was higher than in a study conducted in a provincial hospital in Kenya, where only $40 \%$ of HCWs was vaccinated [17]. Though there was a slightly higher coverage of $\mathrm{HBV}$ vaccination, still our findings showed below WHO expectations, 100\%. The potential reasons for the low HBV vaccine coverage might be the unavailability of the vaccine at the health facility due to high cost and irregular distribution, especially in the developing countries.

Even though the availability of $\mathrm{HBV}$ vaccine is a good progress, $\mathrm{HCW}$ s have to protect themselves from other dangerous pathogens like HIV and HCV due to exposure of HCWs to BBFs. In our study, $\mathrm{HCWs}$ being vaccinated were 1.82 times $(\mathrm{AOR}=1.82$, $95 \% \mathrm{CI} 1.08,3.03)$ and 2.04 times $(\mathrm{AOR}=2.04,95 \%$ CI: $1.22,3.33)$ more exposed to splash and NSI than their counterparts, respectively. The reasons might be negligence and being careless during blood and body fluid samples process. However, HCWs have to develop awareness that exposure to splash and NSI brings a wide range of blood-borne dangerous pathogens such as HIV and HCV. 
Table 4 Multivariate logistic regression analysis of risk factors associated with blood and body fluids in the past year exposure to blood and body fluids

\begin{tabular}{|c|c|c|c|c|c|}
\hline \multirow[t]{2}{*}{ Variables } & \multicolumn{2}{|c|}{ Exposure to BBFs } & \multirow[t]{2}{*}{ COR $(95 \%$ Cl) } & \multirow[t]{2}{*}{ AOR $(95 \% \mathrm{Cl})$} & \multirow[t]{2}{*}{$P$ value } \\
\hline & Yes & No & & & \\
\hline \multicolumn{6}{|l|}{ Age (in years) } \\
\hline $18-30$ & 93 & 76 & 1.00 & & \\
\hline $31-40$ & 58 & 39 & $1.22(0.73-2.02)$ & & \\
\hline$>40$ & 14 & 2 & $5.72(1.26-2595)$ & & \\
\hline \multicolumn{6}{|l|}{ Job } \\
\hline Nurse & 99 & 81 & 1.00 & & \\
\hline Laboratory & 20 & 7 & $2.34(0.94-5.8)$ & & \\
\hline Doctor & 11 & 2 & $4.5(0.97-20.89)$ & & \\
\hline Midwife & 15 & 12 & $1.02(0.45-2.31)$ & & \\
\hline Others & 20 & 15 & $1.09(0.53-2.270)$ & & \\
\hline \multicolumn{6}{|l|}{ Department } \\
\hline Outpatients & 33 & 34 & 1.00 & & \\
\hline Injection and dressing & 12 & 4 & $3.09(0.91-10.56)$ & & \\
\hline Surgical ward & 12 & 6 & $2.06(0.69-6.13)$ & & \\
\hline Operating theater & 13 & 14 & $0.96(0.39-2.34)$ & & \\
\hline Pediatrics & 9 & 8 & $1.16(0.4-3.34)$ & & \\
\hline Gynecology & 30 & 16 & $1.93(0.89-4.19)$ & & \\
\hline Laboratory & 18 & 7 & $2.56(0.98-7.17)$ & & \\
\hline Medical ward & 21 & 9 & $2.4(0.96-6.01)$ & & \\
\hline Others & 17 & 19 & $0.92(0.41-2.07)$ & & \\
\hline \multicolumn{6}{|l|}{ Experience (in years) } \\
\hline$<2$ & 28 & 28 & 1.00 & & \\
\hline $2-5$ & 75 & 52 & $1.44(0.77-2.71)$ & & \\
\hline $6-9$ & 42 & 30 & $1.4(0.69-2.83)$ & & \\
\hline$>=10$ & 20 & 6 & $3.33(1.16-9.55)$ & & \\
\hline \multicolumn{6}{|c|}{ Training on infection prevention } \\
\hline Yes & 79 & 32 & 1.00 & 1.00 & 0.006 \\
\hline No & 86 & 85 & $0.41(0.25-0.68)$ & $0.47(0.27-0.8)$ & \\
\hline \multicolumn{6}{|c|}{ Practicing universal precaution and safety } \\
\hline Yes & 80 & 44 & 1.00 & & \\
\hline No & 85 & 73 & $0.64(0.4-1.04)$ & & \\
\hline \multicolumn{6}{|l|}{ Wearing of eye goggle } \\
\hline Yes & 20 & 23 & 1.00 & 1.00 & 0.02 \\
\hline No & 145 & 94 & $1.77(0.92-3.41)$ & $2.29(1.14-4.6)$ & \\
\hline \multicolumn{6}{|c|}{ Availability of enough hand washing facilities } \\
\hline Yes & 125 & 78 & 1.00 & & \\
\hline No & 40 & 39 & $0.64(0.38-1.08)$ & & \\
\hline \multicolumn{6}{|l|}{ Presence of safety sign } \\
\hline Yes & 36 & 37 & 1.00 & & \\
\hline No & 129 & 80 & $1.66(0.97-2.84)$ & & \\
\hline \multicolumn{6}{|l|}{ HBV vaccination } \\
\hline Yes & 104 & 52 & 1.00 & 1.00 & 0.025 \\
\hline No & 61 & 65 & $0.47(0.29-0.76)$ & $0.55(0.33-0.93)$ & \\
\hline \multicolumn{6}{|l|}{ Recapping of used needle } \\
\hline Yes & 91 & 37 & $2.66(1.62-4.37)$ & $2.22(1.32-3.74)$ & 0.003 \\
\hline No & 74 & 80 & 1.00 & 1.00 & \\
\hline
\end{tabular}


Table 5 Multivariate logistic regression analysis of risk factors associated with NSI in the past year exposure to blood and body fluids

\begin{tabular}{|c|c|c|c|c|c|}
\hline \multirow[t]{2}{*}{ Variables } & \multicolumn{2}{|c|}{ Exposure to BBFs } & \multirow[t]{2}{*}{ COR $(95 \% \mathrm{Cl})$} & \multirow[t]{2}{*}{ AOR $(95 \% \mathrm{Cl})$} & \multirow[t]{2}{*}{$P$ value } \\
\hline & Yes & No & & & \\
\hline \multicolumn{6}{|l|}{ Age (in years) } \\
\hline $18-30$ & 64 & 105 & 1.00 & & \\
\hline $31-40$ & 44 & 53 & $1.36(0.82-2.26)$ & & \\
\hline$>40$ & 11 & 5 & $3.61(1.2-10.86)$ & & \\
\hline \multicolumn{6}{|l|}{ Department } \\
\hline Outpatients & 26 & 41 & 1.00 & & \\
\hline Injection and dressing & 11 & 5 & $3.47(1.08-11.13)$ & & \\
\hline Surgical ward & 9 & 9 & $1.58(0.55-4.49)$ & & \\
\hline Operating theater & 11 & 16 & $1.08(0.44-2.7)$ & & \\
\hline Pediatrics & 7 & 10 & $1.1(0.37-3.26)$ & & \\
\hline Gynecology & 24 & 22 & $1.72(0.81-3.68)$ & & \\
\hline Laboratory & 7 & 18 & $0.61(0.23-1.67)$ & & \\
\hline Medical ward & 10 & 20 & $0.79(0.32-1.95)$ & & \\
\hline Others & 14 & 22 & $1(0.44-2.3)$ & & \\
\hline \multicolumn{6}{|c|}{ Training on infection prevention } \\
\hline Yes & 55 & 56 & 1.00 & & \\
\hline No & 64 & 107 & $0.61(0.38-0.99)$ & & \\
\hline \multicolumn{6}{|l|}{ Wearing of eye goggle } \\
\hline Yes & 14 & 29 & 1.00 & & \\
\hline No & 105 & 134 & $1.62(0.82-3.23)$ & & \\
\hline \multicolumn{6}{|c|}{ Availability of enough hand washing facilities } \\
\hline Yes & 90 & 113 & 1.00 & & \\
\hline No & 29 & 50 & $0.73(0.43-1.24)$ & & \\
\hline \multicolumn{6}{|l|}{ Presence of safety sign } \\
\hline Yes & 25 & 48 & 1.00 & & \\
\hline No & 94 & 115 & $1.57(0.9-2.73)$ & & \\
\hline \multicolumn{6}{|c|}{ Presence of infection prevention committee } \\
\hline Yes & 40 & 43 & 1.00 & & \\
\hline No & 79 & 120 & $0.71(0.42-1.19)$ & & \\
\hline \multicolumn{6}{|l|}{ HBV vaccination } \\
\hline Yes & 80 & 76 & 1.00 & 1.00 & 0.006 \\
\hline No & 39 & 87 & $0.43(0.26-0.7)$ & $0.49(0.3-0.82)$ & \\
\hline \multicolumn{6}{|l|}{ Recapping of used needle } \\
\hline Yes & 71 & 57 & $2.75(1.69-4.48)$ & $2.45(1.49-4.03)$ & 0.000 \\
\hline No & 48 & 106 & 1.00 & & \\
\hline
\end{tabular}

The previous study in occupational exposure and behavior of health care workers in Ethiopia shows needle recapping as a major cause of NSI [11]. Our study showed a higher prevalence of needle recapping after use $(44.7 \%(126))$, which was greater than the studies conducted in Nigeria (35.3\%) [24] and Northern Ethiopia (34.7\%) [25]. HCWs who practiced needle recapping were 2.45 times more likely to experience an injury than who did not recap needles after use $(\mathrm{AOR}=2.45,95 \% \mathrm{CI}$ $1.49,4.03)$. The reason for this difference may be related to improper practice and lack of adequate training on infection prevention, negligence, workload, and lack of safety devices.

Showing the current picture of occupational exposure to BBFs could be taken as the strength of the study. However, this study has limitations due to a cross-sectional study design in which social desirability bias is a problem, and also this study was based on self-report about previous 1 year and lifetime occupational exposure to BBFs; this may affect the result by recall bias. 


\section{Conclusion}

This study showed higher percentage of occupational exposure to blood and body fluids among health care workers in the study area. Lack of training on prevention of occupational infection, $\mathrm{HBV}$ vaccine status, and recapping needles were found to be independent predictors of occupational exposure to BBFs among HCWs. Based on the current assessment, relevant stakeholders need to provide training on prevention of occupational infection to HCWs, arrange provision of infection prevention supplies, formulate strategies to create a favorable working environment, and increase their adherence to universal precautions.

\section{Abbreviations}

HBV: Hepatitis B virus; HCV: Hepatitis C virus; HCWs: Health care workers; HIV: Human immune deficiency virus; NSI: Needlestick injury; PPE: Personal protective equipment

\section{Acknowledgements}

We would like to thank all participants in this study and University of Gondar Comprehensive Hospital officials for the success of the study.

\section{Funding}

There was no funding of the research.

\section{Availability of data and materials}

All data generated or analyzed during this study are included in this article.

\section{Authors' contributions}

JY carried out the conception of the research idea, study design, analysis, and interpretation of the data. RF, FM, and KY participated in the data collection, analysis, and interpretation. KY wrote the manuscript. All authors read and approved the final manuscript.

\section{Ethics approval and consent to participate}

Ethical approval was obtained from the research and ethics review committee of School of Biomedical and Laboratory Sciences, University of Gondar. All the study participants were informed about the purpose of the study and their right to refuse participation or terminate their involvement during the study. Finally, written consent were obtained from the study participants before data collection. All Information provided by each respondent was kept confidential.

\section{Consent for publication}

Not applicable

\section{Competing interests}

The authors declare that they do not have competing interests.

\section{Publisher's Note}

Springer Nature remains neutral with regard to jurisdictional claims in published maps and institutional affiliations.

\footnotetext{
Author details

${ }^{1}$ Department of Nutrition, Institute of Public Health, College of Medicine and Health Sciences, University of Gondar, P.O. Box 196, Gondar, Ethiopia. ${ }^{2}$ Department of Microbiology, School of Biomedical and Laboratory Sciences, College of Medicine and Health Sciences, University of Gondar, P.O. Box 196, Gondar, Ethiopia. ${ }^{3}$ Department of Clinical Chemistry, School of Biomedical and Laboratory Sciences, College of Medicine and Health Sciences, University of Gondar, P.O. Box 196, Gondar, Ethiopia.
}

Received: 9 November 2018 Accepted: 24 February 2019

Published online: 09 March 2019

\section{References}

1. Organization $\mathbf{W H}$. Responding to intimate partner violence and sexual violence against women: WHO clinical and policy guidelines: World Health Organization; 2013.

2. Ngatu NR, Phillips EK, Wembonyama OS, Hirota R, Kaunge NJ, Mbutshu LH, et al. Practice of universal precautions and risk of occupational blood-borne viral infection among Congolese health care workers. Am J Infect Control. 2012:40(1):68-70 e1.

3. Wicker S, Cinatl J, Berger A, Doerr HW, Gottschalk R, Rabenau HF. Determination of risk of infection with blood-borne pathogens following a needlestick injury in hospital workers. Ann Occup Hyg. 2008;52(7):615-22.

4. Yimechew Z, Tiruneh G, Ejigu T, Ajibade V, Ajenifuja O, Dzomba P, et al. Occupational exposures to blood and body fluids (BBFS) among health care workers and medical students in University of Gondar Hospital, northwest of Ethiopia. Glob J Med Res Microbiol Pathol. 2013;13:17-23.

5. Behrman AJ, Shofer FS, Green-McKenzie J. Trends in bloodborne pathogen exposure and follow-up at an urban teaching hospital: 1987 to 1997. J Occup Environ Med. 2001;43(4):370-6

6. Service UPH. Updated US Public Health Service guidelines for the management of occupational exposures to HBV, HCV, and HIV and recommendations for postexposure prophylaxis. MMWR Recomm Rep. 2001;50(RR-11):1.

7. Control CfD, Prevention. Division of Healthcare Quality Promotion. Surveillance of healthcare personnel with HIV/AIDS, as of December 2001. 2003.

8. Control CfD, Prevention. Exposure to blood: what healthcare personnel need to know. Exposure to blood: what healthcare personnel need to know: CDC; 2003.

9. Organization WH. World health statistics 2010: World Health Organization; 2010

10. Belyhun Y, Maier M, Mulu A, Diro E, Liebert UG. Hepatitis viruses in Ethiopia: a systematic review and meta-analysis. BMC Infect Dis. 2016;16(1):761.

11. Reda AA, Fisseha S, Mengistie B, Vandeweerd J-M. Standard precautions: occupational exposure and behavior of health care workers in Ethiopia. PLoS One. 2010;5(12):e14420.

12. Yenesew MA, Fekadu GA. Occupational exposure to blood and body fluids among health care professionals in Bahir Dar town, Northwest Ethiopia. Safety and health at work. 2014;5(1):17-22.

13. Lee R. Occupational transmission of bloodborne diseases to healthcare workers in developing countries: meeting the challenges. J Hosp Infect. 2009;72(4):285-91.

14. Marković-Denić L, Oštrić I, Pavlović A, Kalimanovska-Oštrić D. Knowledge and occupational exposure to blood and body fluids among health care workers and medical students. Acta chirurgica iugoslavica. 2012;59(1):71-5.

15. Naderi H, Sheybani F, Bojdi A, Mostafavi I, Khosravi N. Occupational exposure to blood and other body fluids among health care workers at a university hospital in Iran. Workplace health \& safety. 2012;60(10):419-22.

16. Sharma R, Rasania S, Verma A, Singh S. Study of prevalence and response to needle stick injuries among health care workers in a tertiary care hospital in Delhi, India. Indian J Community Med. 2010;35(1):74.

17. Mbaisi EM, Wanzala P, Omolo J. Prevalence and factors associated with percutaneous injuries and splash exposures among health-care workers in a provincial hospital, Kenya, 2010. Pan Afr Med J. 2013;14(1). https://doi.org/ 10.11604/pamj.2013.14.10.1373.

18. Garcia LP, Facchini LA. Exposures to blood and body fluids in Brazilian primary health care. Occup Med. 2009;59(2):107-13.

19. Bekele T, Gebremariam A, Kaso M, Ahmed K. Factors associated with occupational needle stick and sharps injuries among hospital healthcare workers in Bale Zone, Southeast Ethiopia. PLoS One. 2015;10(10):e0140382.

20. Schulte PA, Chun $\mathrm{H}$. Climate change and occupational safety and health: establishing a preliminary framework. J Occup Environ Hyg. 2009;6(9):542-54.

21. Gebresilassie A, Kumei A, Yemane D. Standard precautions practice among health care workers in public health facilities of Mekelle special zone, Northern Ethiopia. J Community Med Health Educ. 2014;4(3):286.

22. Kermode M, Jolley D, Langkham B, Thomas MS, Holmes W, Gifford SM. Compliance with universal/standard precautions among health care workers in rural North India. Am J Infect Control. 2005;33(1):27-33.

23. Aynalem Tesfay F, Dejenie HT. Assessment of prevalence and determinants of occupational exposure to HIV infection among healthcare workers in selected health institutions in debre Berhan town, north shoa zone, Amhara 
region, Ethiopia, 2014. AIDS research and treatment. 2014;2014. https://doi. org/10.1155/2014/731848.

24. Adejumo PO. Exposure to work-related sharp injuries among nurses in Nigeria. J Nurs Educ Pract. 2013;4(1):229.

25. Walle L, Abebe E, Tsegaye M, Franco H, Birhanu D, Azage M. Factors associated with needle stick and sharp injuries among healthcare workers in Felege Hiwot Referral Hospital, Bahir Dar, Northwest Ethiopia: facility based cross-sectional survey. Int J Infect Control. 2013;9(4). https://doi.org/10.3396/ ijic.v9i4.11709.

Ready to submit your research? Choose BMC and benefit from:

- fast, convenient online submission

- thorough peer review by experienced researchers in your field

- rapid publication on acceptance

- support for research data, including large and complex data types

- gold Open Access which fosters wider collaboration and increased citations

- maximum visibility for your research: over $100 \mathrm{M}$ website views per year

At BMC, research is always in progress.

Learn more biomedcentral.com/submissions 